\title{
Cough and Cold Remedies: a Potential Danger to Patients on Monoamine Oxidase Inhibitors
}

\author{
M. F. CUTHBERT,* M.B., PH.D. ; M. P. GREENBERG, $\dagger$; S. W. MORLEY†
}

$S^{\text {un }}$ mmary : Experiments have been carried out in healthy volunteers to study the effects of phenylpropanolamine on the blood pressure and possible interactions with monamine oxidase inhibitors.

In three subjects $50 \mathrm{mg}$. of phenylpropanolamine taken orally produced a modest rise of systolic pressure. Two proprietary preparations containing this dose in a slowrelease form had no significant effect on the blood pressure. In all three subjects $100 \mathrm{mg}$. of phenylpropanolamine taken orally caused a nore pronounced rise of systolic pressure and a rise of diastolic pressure.

In contrast, $50 \mathrm{mg}$. of phenylpropanolamine orally caused a rapid and potentially dangerous rise of blood pressure in a subject taking the monamine oxidase inhibitor tranylcypromine, and a similar acute rise of blood pressure occurred in this subject when given a proprietary cough linctus containing the same dose of phenylpropanolamine. These and other results suggest that severe hypertensive episodes are more likely to occur when preparations containing phenylpropanolamine in a free form, rather than in slow-release form, are taken by patients being treated with monoamine oxidase inhibitors.

The acute rise of blood pressure due to the interaction of phenylpropanolamine and monoamine oxidase inhibitors was reversed by intramuscular injection of phentolamine.

\section{Introduction}

Phenylpropanolamine is a constituent of a number of proprietary preparations for the relief of cough and syniptoms of the common cold. The present study was carried out to determine the effect of phenylpropanolamine on the blood pressure in man in doses which might be taken by individuals not under medical supervision, and also to study possible interaction with monoamine oxidase inhibitors. This was felt to be of particular importance, since some other amines-for example, tyramine and phenylephrine-are known to be capable of producing hypertensive crises when given to individuals concurrently receiving a monoamine oxidase inhibitor (Blackwell, 1963 ; Blackwell and Marley, 1964 ; Elis, Laurence, Mattie, and Prichard, 1967).

In structure phenylpropanolamine is a sympathomimetic amine closely related tc both adrenaline and ephedrine (Fig. 1).

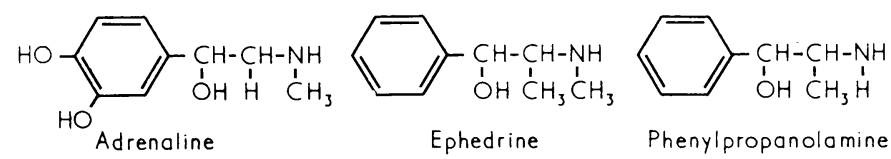

FIG. 1.-Structure of phenylpropanolamine and related preparations.

The pharmacological actions of phenylpropanolamine are similar to those of ephedrine, though it causes less central stimulation. We have been unable to find any detailed account

* Lecturer in Clinical Pharmacology.

* Lecturer in Clinical

Department of Pharmacology and Therapeutics, London Hospital Medical College, London E.1. in the literature of the cardiovascular effects, but it seems likely that phenylpropanolamine acts like ephedrine, causing a rise of blood pressure by displacing noradrenaline from stores in sympathetic nerve endings and by a direct action on vascular smooth muscle (Innes and Nickerson, 1965).

\section{Methods}

The three of us, all healthy males, were studied. A light meal was taken about one hour before the experiments, and during the period of observation the subject rested on a couch with raised back-rest. The blood pressure was measured with a modified mercury sphygmomanometer (Garrow, 1963 ; Dunne, 1969) which incorporated a "zero-muddling" device which made it possible for a random addition of between 0 and $40 \mathrm{~mm}$. of mercury to be introduced before each reading of the blood pressure. The observer was unaware of the addition introduced and the blood pressure was recorded in the usual way, the correction to be subtracted being noted by a second observer. In all experiments the blood pressure and pulse rate were taken in duplicate every 20 minutes and the mean was calculated.

Drugs.-Gelatin capsules of identical appearance, containing $50 \mathrm{mg}$. of phenylpropanolamine hydrochloride, or $50 \mathrm{mg}$. of phenylpropanolamine and $6.25 \mathrm{mg}$. of trimeprazine tartrate, or lactic acid, were supplied by May \& Baker Ltd. The following proprietary preparations were used: Procol capsules containing $50 \mathrm{mg}$. of phenylpropanolamine hydrochloride and isopropamide $2.5 \mathrm{mg}$. in a slow-release form; Contac 400 capsules containing $50 \mathrm{mg}$. of phenylpropanolamine hydrochloride and belladonna alkaloids calculated as hyoscyamine $0.25 \mathrm{mg}$. in a slow-release form; Parnate tablets containing $10 \mathrm{mg}$. of tranylcypromine sulphate ; Vallex expectorant linctus containing $20 \mathrm{mg}$. of phenylpropanolamine hydrochloride and $2.5 \mathrm{mg}$. of trimeprazine tartrate in each $5 \mathrm{ml}$. together with menthol, guaiphenesin, citric acid, sodium citrate, and ipecacuanha liquid extract. All the above preparations were given orally. Phentolamine mesylate (Rogitine was given if necessary in a dose of $5 \mathrm{mg}$. intramuscularly.

\section{Results}

Each of the three subjects received a different treatment on five separate occasions. After administration of the placebo there was a slight reduction in the systolic pressure, diastolic pressure, and pulse rate during the course of the experiment. A modest rise in the systolic pressure was noted in all three subjects after the administration of $50 \mathrm{mg}$. of phenylpropanolamine in a gelatin capsule by mouth (Fig. 2). The systolic pressure rose between 18 and $26 \mathrm{~mm}$. but did not exceed $142 \mathrm{~mm}$. There was no significant change in the diastolic pressure or pulse rate. A more pronounced rise of systolic pressure was noted in all three subjects when $100 \mathrm{mg}$. of phenylpropanolamine was given by mouth, and there was a rise in the diastolic pressure but little change in the pulse rate (Fig. 2). The rise in blood pressure varied, maximum systolic pressures of $157 \mathrm{~mm}$., $134 \mathrm{~mm}$., and $177 \mathrm{~mm}$., with corresponding diastolic pressures of $123 \mathrm{~mm}$., $97 \mathrm{~mm}$., and $109 \mathrm{~mm}$. 
being recorded. In all three subjects the blood pressure did not return to normal levels for three to four hours. When $50 \mathrm{mg}$. of phenylpropanolaminc was given in a slow-release form combined with an atropine-like compound as Procol or Contac 400 there was no significant change in the systolic or diastolic blood pressure or pulse rate; these findings are in agreement with those of Mitchell (1968).

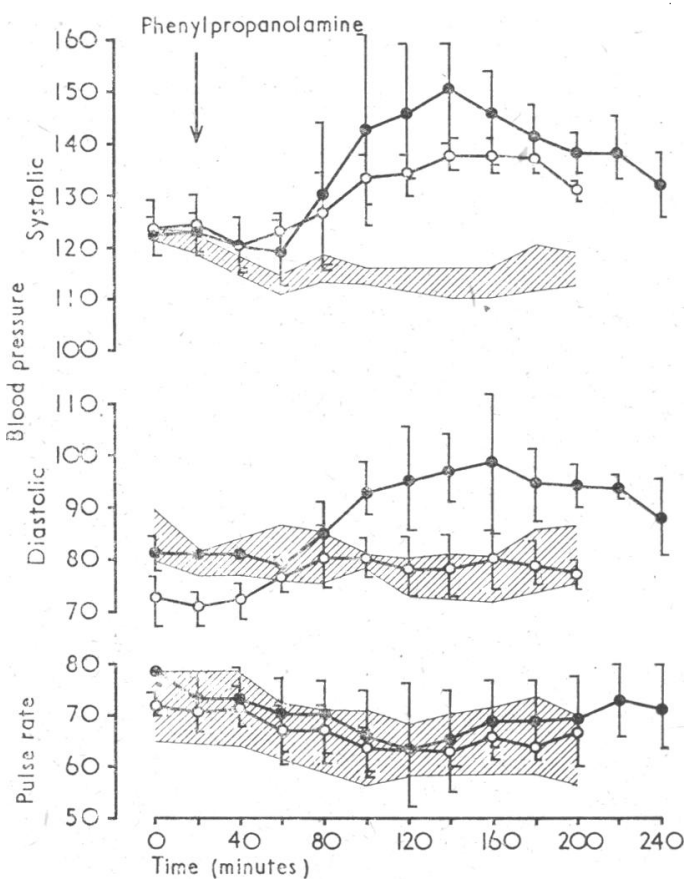

FIG. 2.-Record of blood pressure and pulse rate of three male subjects following administration of phenylpropanolamine by mouth (O $50 \mathrm{mg}$.; $100 \mathrm{mg}$.). Means and standard error of means are shown. Shaded Means and standard en pulse after administration of a placebo by mouth $t$ and pulse after administration of a placebo by mouth \pm on standard error of mean.

Experiments were performed to decide whether the pressor effect of phenylpropanolamine is modified by the addition of a phenothiazine, such as trimeprazine, which has weak $\alpha$-receptor blocking properties. This compound is present in Vallex linctus. Two subjects (M.P.G. and S.W.M.) received $100 \mathrm{mg}$. of phenylpropanolamine with $12.5 \mathrm{mg}$. of trimeprazine; the proportion of phenylpropanolamine and trimeprazine in the capsules was the same as that contained in Vallex linctus. This preparation produced a rise of blood pressure in both subjects which was very similar to that shown in Fig. 2, and the results did not suggest that the presence of trimeprazine had any important influence on the pressor effect of phenylpropanolamine.

To study the possible interaction with monoamine oxidase inhibitors, one subject (M.F.C.) received phenylpropanolamine capsules, Vallex linctus, and Procol capsules both before and immediately after the non-hydrazine monoamine oxidase inhibitor, tranylcypromine, had been taken in a dose of $30 \mathrm{mg}$. daily for 20 to 30 days. Fig. 3 shows that $50 \mathrm{mg}$. of phenylpropanolamine alone caused a modest rise in the systolic blood pressure, but when the same dose was given after tranylcypromine had been taken there was a rapid and dramatic rise in blood pressure, which reached a level of $210 \mathrm{~mm}$. systolic and $140 \mathrm{~mm}$. diastolic about two hours after ingestion. There was an associated bradycardia and an intense throbbing headache. Fig. 4 shows the results obtained when the same dose of phenylpropanolamine was given in the form of Vallex linctus. Vallex linctus $12.5 \mathrm{ml}$. alone caused a slight rise of the blood pressure, but after tranylcypromine had been taken there was again a very striking potentiation of the pressor activity and the blood pressure changes and subjective effects were similar to those seen in the preceding experiment. In both these experiments on the same subject it was necessary for reasons of safety to reduce the blood pressure by the intramuscular injection of phentolamine.

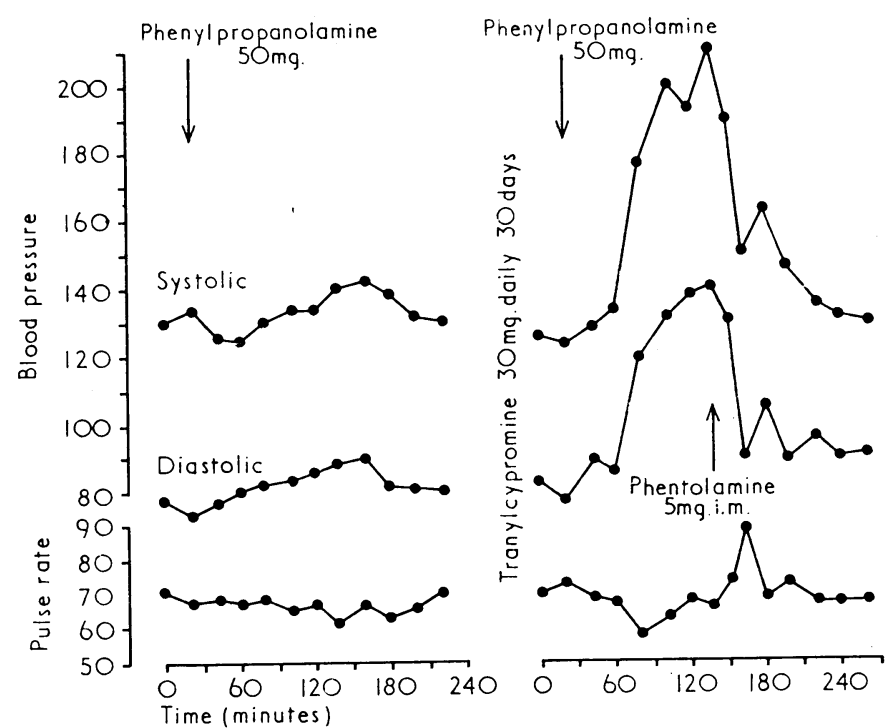

FIG. 3.--Record of blood pressure and pulse rate of a male subject (M.F.C.) following administration of $50 \mathrm{mg}$. of phenylpropanolamine by mouth before and during a course of tranylcypromine.

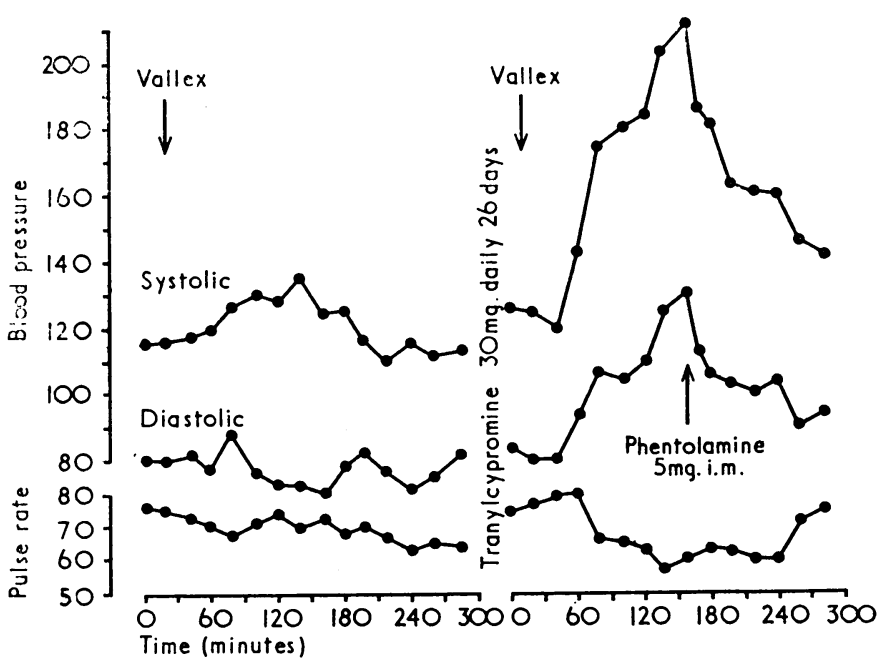

FIG. 4.-Record of blood pressure and pulse rate of the same subject as Fig. 3 following administration of $50 \mathrm{mg}$. of phenylpropanolamine contained in $12.5 \mathrm{ml}$. of Vallex cough linctus before and during a course of tranylcypromine.

The results of a final experiment performed with Procol on the same subject are shown in Fig. 5. There was no detectable effect on blood pressure or pulse when one capsule containing $50 \mathrm{mg}$. of phenylpropanolamine and $2.5 \mathrm{mg}$. of isopropamide in a slow-release form was taken alone, but after tranylcypromine had been taken one Procol capsule caused a gradual rise of blood pressure to $150-160 \mathrm{~mm}$. systolic and 95-100 mm. diastolic about 90 minutes after ingestion. The blood pressure remained at this level for about two hours before returning towards normal. There was slight bradycardia, subjective symptoms were not severe, and it was not necessary to take any measures to reduce the blood pressure.

\section{Discussion}

Blackwell (1963) described hypertensive crises due to the interaction of cheese and monoamine oxidase inhibitors. 
Blackwell and Marley (1964) subsequently showed that this interaction with certain foodstuffs is due to the tyramine which they contain. Tyramine is a substrate for monoamine oxidase and would normally be inactivated in the intestine and liver if monoamine oxidase is inhibited the increased amounts of tyramine absorbed are capable of causing an acute hypertensive reaction by displacing noradrenaline from stores in sympathetic nerve endings. Tonks and Lloyd (1965) suggested the possibility that a similar interaction may occur when patients being treated with monoamine oxidase inhibitors take, as remedies for cough or for the relief of the common cold, drugs which contain sympathomimetic amines. Their report described two patients who, on monoamine oxidase inhibitors, developed an encephalopathy shortly after taking a single capsule of Procol. No direct evidence of a hypertensive episode was obtained in these patients.

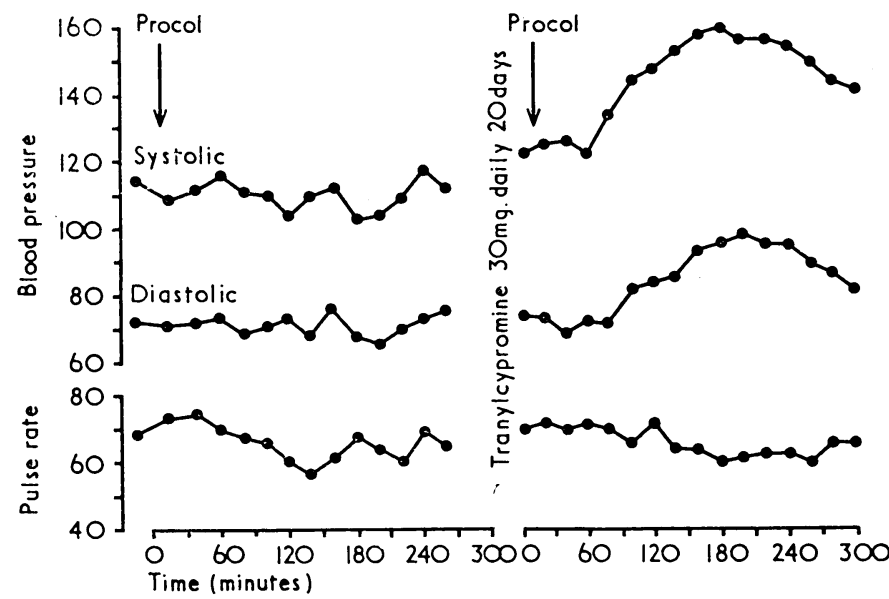

FIG. 5.-Record of blood pressure and pulse rate of the same subject as in Fig. 3 following administration of $50 \mathrm{mg}$. of phenylpropanolamine contained in Procol before and during a course of tranylcypromine.

Elis et al. (1967) carried out a study in normal volunteers to assess the risk in giving commonly used sympathomimetic amines to patients on monoamine oxidase inhibitors. A moderate degree of potentiation occurred with ephedrine, which acts mainly by displacing noradrenaline from tissue stores. Ephedrine is not broken down in the intestine and liver by monoamine oxidase, but phenylephrine, like tyramine, is a substrate for monoamine oxidase, and these workers showed that a very rapid and potentially disastrous rise of blood pressure can occur under experimental conditions when subjects on monoamine oxidase inhibitors are given phenylephrine by mouth.

Phenylpropanolamine appears to be much more popular than phenylephrine as a constituent of cold cures and cough linctuses and is present in the preparations listed in the Appendix, a number of which are freely available to the public without prescription. Phenylpropanolamine is stated to be effective in reducing nasal congestion, and this appears to be the main reason for its inclusion in these preparations (Innes and Nickerson, 1965).

The present results suggest that the effects of phenylpropanolamine on the blood pressure, though minimal in doses likely to be taken in these preparations, may constitute a severe risk to patients taking monoamine oxidase inhibitors, since a marked and rapid rise of blood pressure may occur within two hours. Those preparations in which the phenylpropanolamine is present in free form rather than in slow-release form seem particularly apt to produce severe hypertensive reactions in these patients. The presence of a phenothiazine with weak $\alpha$-receptor blocking properties does not prevent such a reaction from taking place. The experiments did not give any information regarding the action of phenylpropanolamine on the nasal mucosa.
Phenylpropanolamine is a poor substrate for monoamine oxidase (Maxwell, personal communication), and inhibition of monoamine oxidase therefore seems unlikely to be the sole explanation of the acute hypertensive reaction which was seen in these experiments. Rand and Trinker (1968) suggested that some sympathomimetic amines are degraded by non-specific microsomal enzymes in the liver; these enzymes are also inhibited by monoamine oxidase inhibitors. It is possible that a similar mechanism is partly responsible for the marked potentiation of the pressor effect of phenylpropanolamine in the presence of tranylcypromine.

Both patients and physicians should be aware of the danger of taking trivial remedies containing phenylpropanolamine concurrently with treatment involving monoamine oxidase inhibitors.

We should like to thank Dr. A. Herxheimer for his advice, particularly in the initial stages of this work; Dr. C. R. B. Joyce and Dr. D. W. Vere for helpful criticism of the manuscript; and A. Pruss, medical student, for assisting with these time-consuming experiments. We are ailso indebted to Dr. D. R. Maxwell, of May \& Baker Ltd., who kindly arranged in-vitro studies on phenylpropanolamine.

\section{REFERENCES}

Blackwell, B. (1963). Lancet, 2, 849.

Blackwell, B., and Marley, E. (1964). Lancet, 1, 530

Dunne, J. F. (1969). Lancet. In press.

Elis, J., Laurence, D. R., Mattie, H., and Prichard, B. N. C. (1967). Brit. med. $\mathcal{f} ., 2,75$.

Garrow, J. S. (1963). Lancet, 2, 1205.

Innes, I. R., and Nickerson, M. (1965). In The Pharmacological Basis of Therapeutics, 3rd ed., edited by L. S. Goodman and A. Gilman, p. 477. New York.

Mitchell, C. A. (1968). Curr. ther. Res., 10, 47

Rand, M. J., and Trinker, F. R. (1968). Brit. F. Pharmacol., 33, 287.

Tonks, C. M., and Lloyd, A. T. (1965). Brit. med. f., 1, 589.

\section{Appendix}

Proprietary Preparations Containing Phenylpropanolamine

\begin{tabular}{|c|c|c|c|}
\hline & Formulation & $\begin{array}{l}\text { Phenylpropanol- } \\
\text { amine Content } \\
\text { per Tablet }\end{array}$ & Recommended Dose \\
\hline \multicolumn{4}{|c|}{ Tablets and Capsules } \\
\hline $\begin{array}{l}\text { Mucron } \\
\text { Rinurel }\end{array}$ & 二 & $\begin{array}{ll}32 & \mathrm{mg} \\
25 & \mathrm{mg}\end{array}$ & $\begin{array}{l}1 \text { tab. } 2-3 \text { times daily } \\
2 \text { tab. initially, then } \\
14 \text {-hourly }\end{array}$ \\
\hline $\begin{array}{l}\text { Contac } 400 \\
\text { Eskornade } \\
\text { Procol } \\
\text { Rinurel SA } \\
\text { Triogesic } \\
\text { Triominic } \\
\text { Triotussic }\end{array}$ & $\begin{array}{l}\text { Slow release } \\
\text { Slow release } \\
\text { Slow release } \\
\text { Slow release } \\
\text { Slow release } \\
\text { Slow release } \\
\text { Slow release }\end{array}$ & $\begin{array}{cc}50 & \mathrm{mg} . \\
50 & \mathrm{mg} . \\
50 & \mathrm{mg} . \\
100 & \mathrm{mg} . \\
12.5 \mathrm{mg} . \\
50 & \mathrm{mg} . \\
12.5 \mathrm{mg} .\end{array}$ & $\begin{array}{l}1 \text { cap. 12-hourly } \\
1 \text { spansule } 12 \text {-hourly } \\
1 \text { cap. 12-hourly } \\
1 \text { tab. 12-hourly } \\
1 \text { tab. 3-4 hourly } \\
1 \text { tab. 6-8-hourly } \\
2 \text { tab. 6-8-hourly }\end{array}$ \\
\hline \multicolumn{4}{|c|}{ Syrups and Linctuses } \\
\hline & & $\begin{array}{l}\text { Phenylpropanol- } \\
\text { amine Content } \\
\text { per } 5 \mathrm{ml} \text {. }\end{array}$ & \\
\hline Delexin & $\begin{array}{l}\text { Expectorant } \\
\text { Expectorant }\end{array}$ & $\begin{array}{l}12.5 \mathrm{mg} \text {. } \\
5 \mathrm{mg} \text {. }\end{array}$ & $\begin{array}{l}10 \mathrm{ml} .3 \text { or } 4 \text { times daily } \\
5-10 \mathrm{ml} .4 \text { or more times } \\
\text { daily }\end{array}$ \\
\hline *Eskornade & Syrup & $15 \mathrm{mg}$. & $\begin{array}{l}\text { For children, } 1 \cdot 25-5 \mathrm{ml} \text {. } \\
3 \text { times daily according tc } \\
\text { age }\end{array}$ \\
\hline $\begin{array}{l}\text { Galaton } \\
\text { Rinurel } \\
\text { * Syrtussar }\end{array}$ & $\begin{array}{l}\text { Syrup } \\
\text { Linctus }\end{array}$ & $\begin{aligned} 25 & \text { mg. } \\
25 & \text { mg. } \\
5 & \text { mg. }\end{aligned}$ & $\begin{array}{l}10 \mathrm{ml} .3-4 \text { times daily } \\
10 \mathrm{ml} .3-4 \text { times daily } \\
5 \mathrm{ml} .3-4 \text { times daily }\end{array}$ \\
\hline +*Tixylix & Linctus & $10 \mathrm{mg}$. & $\begin{array}{l}\text { For children, } 2 \cdot 5-10 \mathrm{ml} \text {. } \\
3 \text { times daily; } \\
\text { according to age }\end{array}$ \\
\hline $\begin{array}{l}\text { *Triogesic } \\
\text { *Triominic } \\
\text { *Triotussic } \\
t * \text { Vallex }\end{array}$ & $\begin{array}{l}\text { Elixir } \\
\text { Syrup } \\
\text { Suspension } \\
\text { Linctus }\end{array}$ & $\begin{array}{l}3 \mathrm{mg} . \\
12.5 \mathrm{mg} . \\
12.5 \mathrm{mg} .(4 \mathrm{ml} .) \\
20 \mathrm{mg} .\end{array}$ & $\begin{array}{l}15 \mathrm{ml} .3 \text {-4-hourly } \\
10 \mathrm{ml} \text {. 4-hourly } \\
4-8 \text { m. 3-4-hourly } \\
5-10 \mathrm{ml} .2-3 \text { times daily }\end{array}$ \\
\hline
\end{tabular}

These preparations are recommended for children in appropriate dosage. T The manufacturers have informed us that since the end of November 1968 the
The $10 \mathrm{mg} .15 \mathrm{ml}$. respectively. 